\title{
Enzimrögzítési módszerek nanostruktúrált rendszerekben
}

\author{
BALOGH-WEISER Diána ${ }^{a b^{*}}$ \\ ${ }^{a}$ Budapesti Müszaki és Gazdaságtudományi Egyetem, Szerves Kémia és Technológia Tanszék, \\ Szent Gellért tér 4. 1111, Budapest, Magyarország, \\ ${ }^{b}$ Budapesti Müszaki és Gazdaságtudományi Egyetem, Fizikai Kémia és Anyagtudományi Tanszék, \\ Budafoki út 8. 1111, Budapest, Magyarország
}

\section{Bevezetés}

A modern szintetikus és diagnosztikai eljárások között az enzimkatalizált folyamatok kiemelt fontosságúak, a gyógyszer- és finomkemikália ipar, az élelmiszeripar, a textilipar, az energiatermelés vagy a modern orvostudomány nélkülözhetetlen elemivé váltak. ${ }^{1}$ Enzimekkel hatékonyabban juthatunk az értékes optikailag tiszta vegyületekhez, mint a klasszikus szintetikus útvonalak alkalmazásával. ${ }^{2,3}$ A természetben az enzimek többnyire oldott állapotban müködnek, azonban a homogénfázisú reakciókból izolálásuk igen nehézkes, visszaforgatásuk, regenerálásuk szinte lehetetlen. Komoly problémát jelenthet emellett, hogy az oldott, natív enzim nehezen tolerálja az adott reakció körülményeit, így aktivitását, szelektivitását elveszítheti. Ezekre a komoly technológiai és nem utolsó sorban gazdasági problémákra megoldást jelenthetnek a különböző enzimrögzítési technikák. ${ }^{4,5}$

Napjainkban sokféle enzimrögzítési eljárás létezik, melyek sok esetben jól illeszkednek az adott biotranszformációs folyamat körülményeihez. A modern biotechnológia eszköztárában egyre nagyobb teret hódítanak a két vagy három dimenziójában is nano mérettartományba eső anyagok, az úgynevezett szerkezeti és funkcionális nanoanyagok. Az enzimek és a nanostruktúrált anyagok között hatékony és finomhangolt kölcsönhatások hozhatóak létre, melyek révén egy adott enzim stabilan, vagy akár szelektíven is immobilizálható. Az így előállítható nagy fajlagos felületű nanobiokatalizátorok növelik az anyagtranszport folyamatok sebességét, ami összességében magasfokú katalitikus hatékonyságot eredményez. ${ }^{6} \mathrm{Az}$ enzimek változatos rögzítésére ez idáig sikeresen alkalmaztak különböző nanorészecskéket, belőlük szerveződő nanoszerkezetű mátrix rendszereket, nanopórusos anyagokat, nanoszálakat, nanocsöveket és üreges nanorudakat is. ${ }^{7}$

Doktori munkám célja olyan nanostrukturált anyagok kifejlesztése és vizsgálata volt, melyek alkalmasak lehetnek enzimek immobilizálásra. A kísérletek során alkalmazott enzimek (lipázok és ammónia-liázok) releváns biokatalizátorok ipari és orvos diagnosztikai alkalmazásokban. Részletesen vizsgáltuk a különböző nanoanyagok (nanopórusos térhálók, nanoszálak, nanocsövek és nanorészecskék) segítségével előállított rögzített enzimkészítmények biokatalitikus képességeit és stabilitását.
Kutatásaink egyik célja szol-gél módszerrel előállítható nanoszerkezetü szilícium-dioxid (és hibrid: szubsztituált szilán tartalmú) térhálók előállítása, amelyek képesek enzim molekulákat magukba zárni, rögzített biokatalizátort eredményezve. $^{8}$ A szol-gél térháló prekurzoraiként egyszeresen és kétszeresen szubsztituált organoszilánokat vizsgáltunk, melyek várhatóan nagy hatással lehetnek a térhálóba ágyazott enzim biokatalitikus müködésére és stabilitására. Enzimekből felépített nanopórusos térhálók kialakítása során vizsgáltuk az enzimek között kovalens keresztkötéseket létrehozó bifunkciós ágensek hatását a rögzített enzimkészítmény biokatalitikus müködésére és stabilitására. ${ }^{9}$ Célunk volt egy új keresztkötő ágens révén stabilabb és aktívabb, egyszerüen létrehozható rögzített biokatalizátorok kifejlesztése, melyek jól alkalmazhatóak szerves és vizes közegben végbemenő biotranszfromációkra.

Célunk volt továbbá a nanoszálakban történő enzimrögzítés vizsgálata elektrosztatikus szálképzés segítségével. ${ }^{10} \mathrm{~A}$ nanoszálba ágyazás során nem-ionos felületaktív anyagokat és organoszilánokat alkalmaztunk additívként, melyek befolyásolhatják a rögzített enzim biokatalitikus képességeit. Szén nanocsövek különböző felületi funkcionalizálása révén olyan hordozók előállítását terveztük, melyek képesek lehetnek enzimek stabil és hatékony rögzítésére. ${ }^{11}$ Végezetül enzimrögzítésre alkalmas mágneses nanorészecskék előállítását céloztuk meg, melyek hatékonyan alkalmazhatóak mikrofluidikai rendszerekben megvalósított szelektív biotranszformációkra. ${ }^{12,13}$

\section{Eredmények}

\subsection{Enzimrögzítés szol-gél térhálókban}

Lipázok szol-gél mátrixba zárását kétszeresen szubsztituált organoszilán prekurzorokkal (DPDEOS: difenildietoxiszilán, DMDEOS: dimetildietoxiszilán, MPDEOS: metil,fenildietoxiszilán) valósítottuk meg, melyek ilyen célú alkalmazása nem ismert az irodalomban ezáidáig. Az új prekurzorok hatását, a szakirodalom és korábbi kutatásaink alapján egyszeresen szubsztituált szilánokkal (PTEOS: feniltrietoxiszilán, OTEOS: oktiltrietoxiszilán) hasonlítottuk össze. ${ }^{14,15}$ A különböző prekurzorokkal szol-gélbe ágyazott lipázok biokatalitikus müködését a racém-1-feniletanol (rac-1a) kinetikus reszolválásában vizsgáltuk (1. ábra). 
<smiles>CC(O)c1ccccc1</smiles>

rac-1a

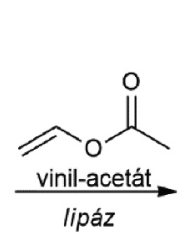<smiles>CC(=O)O[C@@H](C)c1ccccc1</smiles>

$(R)-2 a$<smiles>C[C@@H](O)c1ccccc1</smiles>

(S)-1a 1.ábra. A rac-1a kinetikus reszolválása lipáz biokatalizátorokkal

A szol-gél mátrixba ágyazott lipázokkal végzett reszolválásban képződő termék enantiomertisztasága $\left(e e_{(R)-2 a}\right)$ javult és az elért konverzió $(c)$ szinte minden szol-gél mátrixba ágyazott lipáz esetében meghaladta, a nem rögzített natív lipázzal elértet (1. Táblázat). Míg az enzimkészítmények biokatalitikus aktivitása $\left(U_{B}\right)$ összemérhető a natív lipázéval, addig fajlagos enziaktivitásuk $\left(Y_{A}\right)$ minden esetben többszörösére növekedett, mivel a rögzített lipázkészítmények enzimtartalma jóval kevesebb, mint a natív lipázé. Kiemelkedően jó eredményt mutatott a kétszeresen szubsztituált DMDEOS prekurzor alkalmazása, mellyel megközelíthető volt az elméleti maximális konverzió (c = 47,2\%), nagyfokú enantiomertisztaság mellett $\left(e e_{(R)-\mathbf{2} \mathbf{a}}=99,3 \%\right)$.

1.Táblázat. Natív és szol-gél mátrixban immobilizált lipáz biokatalitikus hatékonysága 4 óra reakcióidő után a rac-1a kinetikus reszolválásában.

\begin{tabular}{lcccrc}
\hline \multicolumn{1}{c}{ Szilán prekurzor } & $\begin{array}{c}c \\
(\%)\end{array}$ & $\begin{array}{c}e e_{(R)-2} \\
(\%)\end{array}$ & $E$ & $\begin{array}{c}U_{\mathrm{B}} \\
\left(\mathrm{U} \mathrm{g} \mathrm{g}^{-1}\right)\end{array}$ & $\begin{array}{c}Y_{\mathrm{A}} \\
(\%)\end{array}$ \\
\hline natív lipáz & 29,7 & 97,9 & $>100$ & 10,0 & 100 \\
TEOS & 27,5 & 98,3 & $\$ 200$ & 9,1 & 350 \\
TEOS:PTEOS & 30,6 & 98,3 & $>100$ & 10,5 & 360 \\
TEOS:OTEOS & 49,4 & 98,3 & $» 200$ & 17,0 & 374 \\
TEOS:DPDEOS & $\mathbf{1 4 , 4}$ & 98,8 & $>100$ & 5,0 & 750 \\
TEOS:MPDEOS & 28,9 & 98,8 & $>200$ & 8,2 & 900 \\
TEOS:DMDEOS & 47,2 & 99,3 & $» 200$ & 16,3 & 994 \\
\hline
\end{tabular}

$\mathrm{Az}$ eddigiekben legjobb eredményeket hozó szol-gél készítményeink visszaforgathatóságát összehasonlítottuk a rögzítetlen lipázzal (natív lipáz AK), és egy az irodalomban egyik jól ismert szol-gél lipázzal (Reetz-TMOS/iBTMOS = 5/1). ${ }^{16}$ A 2. ábrán látható eredmények alapján elmondható, hogy a vizsgált hét visszaforgatási ciklus alatt az általunk előállított szol-gél enzim készítmények aktivitása változatlan maradt, míg a rögzítetlen és kereskedelmi forgalomban kapható szol-gél lipáz jelentősen veszített aktivitásából.

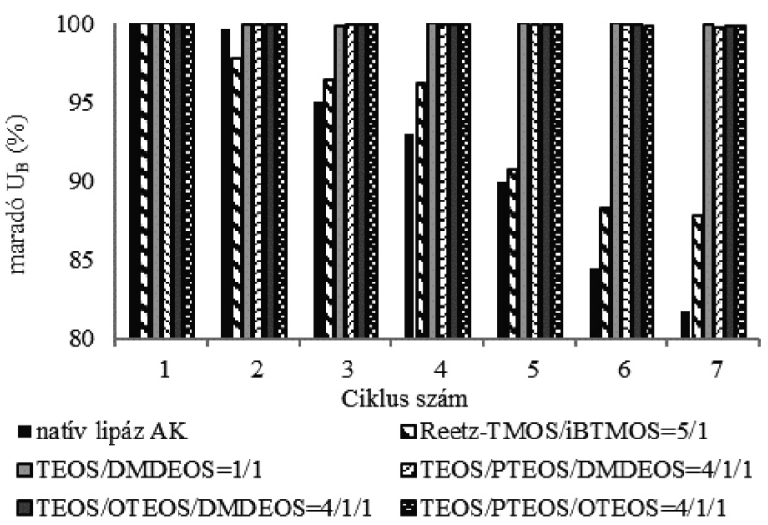

2.Ábra. A lipáz biokatalizátor aktivitás változása (maradó $U_{B}, \%$ ) a rac-1a kinetikus reszolválásában hét visszaforgatási ciklus során.

\subsection{Enzimek rögzítése nanoszálakban elektrosztatikus szálképzés segítségével}

Lipázok poli(vinil-alkohol) (PVA) nanoszálba zárását elektrosztatikus szálképzés segítségével valósítottuk meg, mely során elsőként a szálak enzimrögzítő kapacitását vizsgáltuk Pseudomonas fluorescens lipáz (lipáz AK) esetében (2. Táblázat). Az egyre nagyobb enzim mennyiséget tartalmazó nanoszálakkal végzett $r a c-1 a$ szubsztrát kinetikus reszoláválásban az 5\%-os enzimmennyiség bizonyult előnyösnek, mivel ebben az esetben volt elérhető a legmagasabb specifikus, azaz enzim mennyiségre vonatkoztatott aktivitás $\left(Y_{A}=178 \%\right)$.

2.Táblázat. Különböző enzimmennyiséget tartalmazó PVA nanoszálak által katalizált rac-1a kinetikus reszolválása

\begin{tabular}{|c|c|c|c|c|}
\hline $\begin{array}{c}\text { Enzim tartalom } \\
(\%)\end{array}$ & $\begin{array}{c}c^{\mathrm{a}} \\
(\%)\end{array}$ & $\begin{array}{c}e e_{(R) 2 \mathrm{a}} \\
\mathbf{( \% )}\end{array}$ & $\begin{array}{c}U_{\mathrm{B}} \\
\left(\mathrm{U} \mathrm{g}^{-1}\right)\end{array}$ & $\begin{array}{c}Y_{\mathrm{A}} \\
(\%)\end{array}$ \\
\hline natív enzim & $48,3 \pm 0,03$ & $95,2 \pm 0,03$ & 33,3 & 100 \\
\hline 5 & $4,2 \pm 0,04$ & $99,4 \pm 0,03$ & 2,9 & 178 \\
\hline 10 & $5,9 \pm 0,14$ & $99,4 \pm 0,01$ & 4,1 & 126 \\
\hline 15 & $10,2 \pm 0,18$ & $99,6 \pm 0,03$ & 7,0 & 143 \\
\hline 20 & $18,4 \pm 0,88$ & $99,6 \pm 0,05$ & 12,7 & 169 \\
\hline 25 & $20,6 \pm 1,93$ & $99,5 \pm 0,07$ & 14,2 & 155 \\
\hline $33^{\mathrm{b}}$ & - & - & - & - \\
\hline
\end{tabular}

Az elérhető biokatalitikus aktivitás $\left(U_{B}\right)$ és enantiomertisztaság $\left(e e_{(R)-2 a}\right)$ mellett a biokatalizátor morfológiája, szerkezeti homogenitása is fontos szempont a készítményfejlesztés során. Ezért a különböző enzimtartalmú mintákat pásztázó elektronmikroszkóp (SEM) segítségével is megvizsgáltuk (3. Ábra), ahol azt tapasztaltuk, hogy $5 \%$-os enzimtartalom felett már fehérje aggregátumok, illetve jelentősebb szál heterogenitások jelennek meg a készítményekben. Ez az eredmény egybehangzik a kinetikus reszolválásban tapasztaltakkal, ugyanis az 5\%-nál több lipázt tartalmazó PVA nanoszálak fajlagos enzimaktivitása csökken.

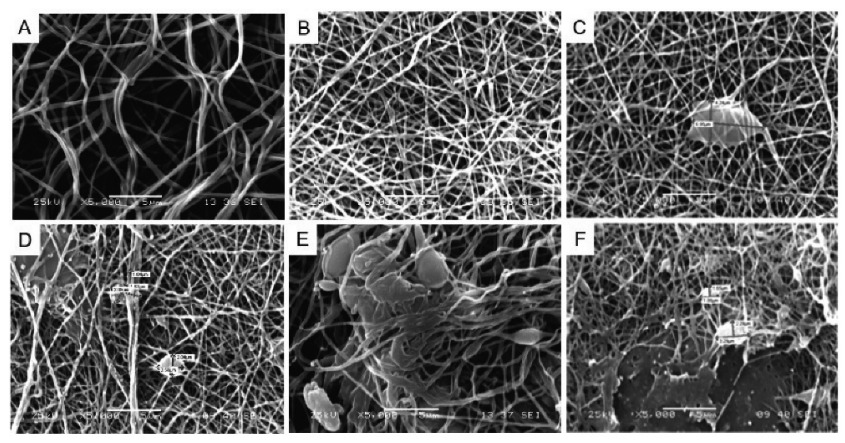

3.Ábra. SEM felvételek a különböző lipáz AK tartalmú PVA nanoszálakról: enzimtartalom $0 \%$ (A), 5\% (B), 10\% (C) 15\% (D), 20\% (E) és 25\% (F).

A PVA nanoszálakban történő enzimrögzítési kísérleteket a Candida antarctica B lipázzal (CaLB) is elvégeztük, azonban ezúttal különböző additívek hatását vizsgáltuk a beágyazott lipázok biokatalitikus működésére (Brij30: polietilén-glikol dodecil éter, PEG400: polietilén-glikol 400, 
PTEOS: feniltrietoxiszilán, OTEOS: oktil-trietoxiszilán). $\mathrm{Az}$ enzimkészítményeket a racém-1-feniletanol ( $\mathrm{rac}-\mathbf{1 a})$, valamint a racém-1-fenil-2-propanol (rac-1b) kinetikus reszolválásában vizsgáltuk (4. Ábra).

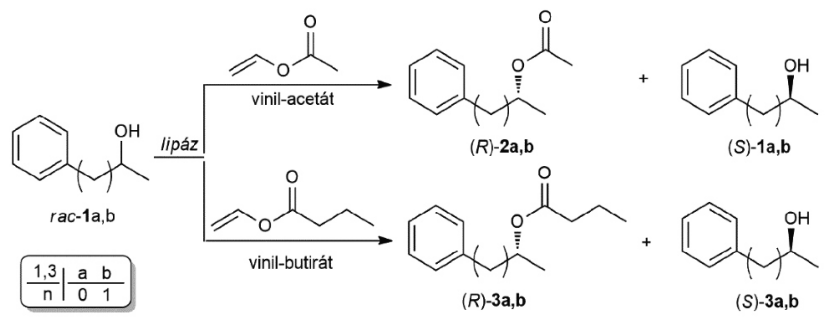

4.Ábra. rac-1a,b kinetikus reszolválása PVA nanoszálakban immobilizált CaLB-vel vinil-acetát és vinil-butirát acilezőszerek jelenlétében.

Az eredmények azt mutatták, hogy a nanoszálakban rögzített lipázok minden esetben jóval meghaladták a natív enzim képességeit, a CaLB enzim fajlagos aktivitása több tízszeresére javult a reszolválási reakciókban a rögzítés során alkalmazott PEG400 és Brij30 additíveknek köszönhetően, a fenil- és oktiltrietoxiszilán (PTEOS és OTEOS) jelenléte bizonyos esetekben szintén fokozta az enzim aktivitást (3. Táblázat).

3.Táblázat. Additívek hatása PVA nanoszálba zárt CaLB biokatalitikus képességeire a rac-1a,b kinetikus reszolválásában.

\begin{tabular}{|c|c|c|c|c|c|c|c|c|c|}
\hline \multirow[t]{2}{*}{ Additiv } & \multicolumn{3}{|c|}{$c(\%)^{\mathrm{a}}$} & \multicolumn{3}{|c|}{$e e(\%)$} & \multicolumn{3}{|c|}{$Y_{A}(\%)$} \\
\hline & $\begin{array}{l}(R)- \\
\mathbf{2 b}\end{array}$ & $\begin{array}{c}(R)- \\
\mathbf{3 a}\end{array}$ & $\begin{array}{c}(R)- \\
\mathbf{3 b}\end{array}$ & $\begin{array}{c}(R)- \\
\mathbf{2 b}\end{array}$ & $\begin{array}{c}(R)- \\
\mathbf{3 a}\end{array}$ & $\begin{array}{c}(R)- \\
\mathbf{3 b}\end{array}$ & $\begin{array}{l}(R)- \\
\mathbf{2 b}\end{array}$ & $\begin{array}{c}(R)- \\
\mathbf{3 a}\end{array}$ & $\begin{array}{c}(R)- \\
\mathbf{3 b}\end{array}$ \\
\hline b & 21,0 & 0,8 & 7,5 & 99,2 & 98,4 & 97,9 & 100 & 100 & 100 \\
\hline- & 5,5 & 0,5 & 4,3 & 98,4 & 96,5 & 99,6 & 280 & 237 & 115 \\
\hline Brij30 & 27,6 & 16,0 & 38,2 & 99,5 & 99,9 & 98,3 & 1311 & 8496 & 6362 \\
\hline PEG400 & 29,6 & 14,0 & 34,3 & 99,5 & 99,7 & 99,0 & 1406 & 7438 & 9157 \\
\hline PTEOS & 3,2 & 0,3 & 2,1 & 98,2 & 95,7 & 98,7 & 158 & 183 & 354 \\
\hline OTEOS & 2,4 & 0,5 & 3,3 & 96,0 & 97,4 & 99,0 & 116 & 269 & 542 \\
\hline
\end{tabular}

A vizsgált additívek közül a Brij 30 és a PEG származékok ismert szubsztrát analógjai a lipázoknak. Alkalmazásukkal elérhető, hogy az enzim aktív konformációjában rögzül a nanoszálba ágyazás során. Organoszilánok szubsztrát analógként kifejtett hatása azonban az irodalomban nem ismert. Pozitív hatásuk megértése okán molekula modellezés segítségével a PTEOS, OTEOS, DMDEOS szilánokat beillesztettük az CaLB aktív centrumába. A modellezés során bizonyítottuk, hogy az organoszilánok szintén kedvező enzim-szubsztrát tetraéderes köztiterméknek megfelelő analóg molekulák, melyek képesek lipázok aktív konformációját fenntartani immobilizálásuk során. Ezzel magyarázható a rögzített enzimkészítmények nagyfokú hatékonysága, amit a kísérleti eredmények is alátámasztottak. ${ }^{17}$

\subsection{Fehérje térhálók, kovalensen keresztkötött enzimaggregátumok}

Fenilalanin ammónia-liáz (PAL) enzimből olyan térhálós aggregátumot állítottunk elő, melyben a fehérje molekulákat egymással az irodalomban eddig nem ismert módon, biszepoxi vegyülettel (glicerin-diglicidil-éter, GDE) kapcsoltuk össze. A PAL molekulák keresztkötését irodalmi példa alapján egy elterjedt keresztkötő ágenssel, glutáraldehiddel (GA) is elvégeztük. A kétféle ágenssel keresztkötött enzimkészítmények mechanikai stabilitását erős ultrahangos behatás segítségével vizsgáltuk. A fényszóródáson alapuló mérések során a készítmények átlagos részecskeméret eloszlását határoztuk meg az ultrahangozási idő függvényében (5. Ábra). Azt tapasztaltuk, hogy míg a biszepoxi vegyülettel keresztkötött (5. Ábra, A) enzim erős ultrahang hatására is stabil maradt, addig a glutáraldehiddel térhálósított enzim jellemző részecske mérete csökkent, ami a készítmény instabilitására, degradációjára utal (5. Ábra, B).
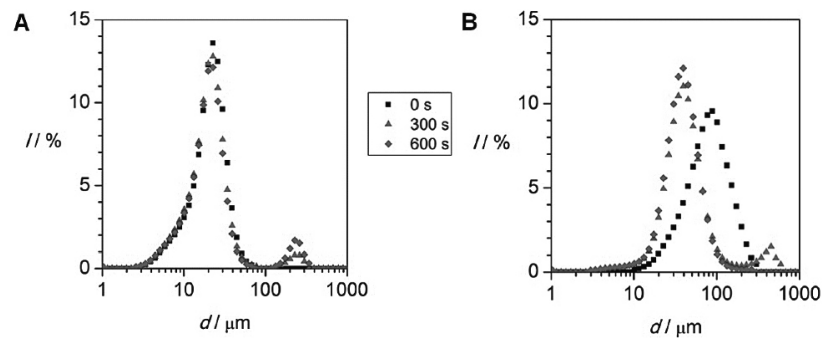

5.Ábra. Glicerin-diglicidil-éter A) és glutáraldehid B) alkalmazásával keresztkötött PAL enzimkészítmények részecskeméret eloszlása az ultrahangozási idő függvényében.

A keresztkötött PAL készítmények biokatalitikus aktivitását úgy a racém-2-amino-3-(tiofén-2-il)propánsavból (rac-3) történő ammónia eliminációban, mint az $(E)$-3-(tiofén2-il)akrilsavra [(E)-4] végmenő ammónia addíciójában vizsgáltuk (6. Ábra).

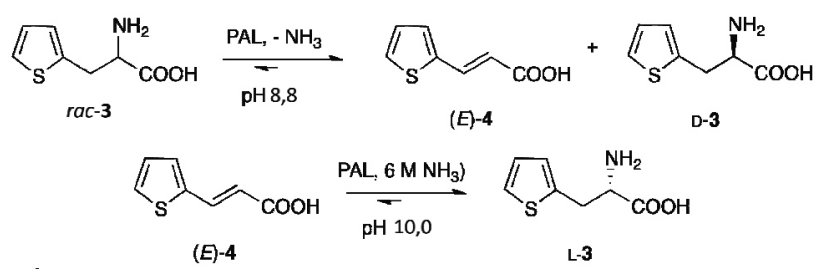

6.Ábra. PAL által katalizált ammónia elimináció és addíció.

A kísérletek során azt tapasztaltuk, hogy mind az eliminációs, mind az addíciós reakcióban a glutáraldehiddel kötött PAL biokatalitikus aktivitása lényegesen alacsonyabb, mint a biszepoxi ágenssel kötött PAL készítményé. Ezen felül a glutáraldehid esetében az enzim már az első ciklus után inaktiválódott (7. ábra). ${ }^{18}$ 

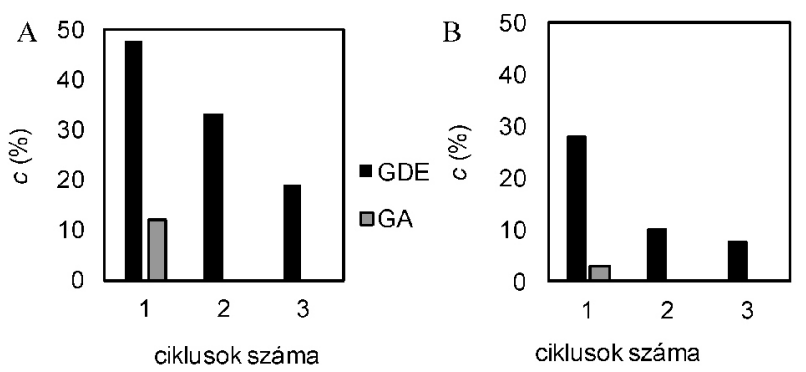

7.Ábra. Keresztkötött PAL enzimkészítmények működése rac-3-ból történő ammónia eliminációban A) és (E)-4-re végbemenő ammónia addícióban B).

\subsection{Kovalens enzimrögzítés szén nanocsöveken}

A fenilalanin ammónia-liáz (PAL) kovalens rögzítését kétféle módszer szerint karboxi-funkcionalizált egyfalú szén nanocső hordozón (SwCNT) végeztük el. Egyik esetben az enzim karboxilcsoportokhoz közvetlenül kapcsolódik a hordozóhoz (SwCNT-A-PAL). A karboxilcsoportokkal funkcionalizált hordozók jól ismertek enzimrögzítési célokra. A másik esetben egy új funkcionalizálási eljárás során a szén nanocsöveken epoxicsoportokat alakítottunk ki, a korábban is jó eredményeket mutató gliceril-diglicidil-éter segítségével, melyen keresztül a PAL kovalensen kötödött a hordozóra (SwCNT-B-PAL). ${ }^{18} \mathrm{Az}$ immobilizált PAL készítményeket a 6 . Ábrán bemutatott eliminációs és az addíciós reakcióban vizsgáltuk hét visszaforgatási cikluson át (4. táblázat). Mindkét hordozótípus esetében az immobilizált PAL hasonló konverziót ért el, valamint a készítmények jó stabilitással bírtak az elimináció vizsgált hét ciklusa alatt. Az ammónia addíció során azonban a SwCNT-A-PAL hordozón savamid kötésekkel rögzült PAL csak három ciklus erejéig volt müködőképes, míg az epoxi csoportokkal kötött PAL négy körön át alig veszített aktivitásából, még a hetedik ciklusban is csekély mértékben ugyan, de müködőképes volt a biokatalizátor.

4.Táblázat. Különbözőképp funkcionalizált szén nanocsöveken rögzített PAL biokatalizátorok (SwCNT-A-PAL és SwCNT-B-PAL)

összehasonlítása rac-3-ból történő ammónia eliminációban és $(E)$-4-re végbemenő ammónia addícióban.

\begin{tabular}{|c|c|c|c|c|}
\hline \multirow[t]{2}{*}{ Ciklus } & \multicolumn{2}{|c|}{$\begin{array}{c}\text { Elimináció } \\
\text { rac-3, TRIS-puffer } \\
c(\%)^{\mathrm{a}}\end{array}$} & \multicolumn{2}{|c|}{$\begin{array}{c}\text { Addició } \\
(E)-4,6 \mathrm{M} \mathrm{NH} 3 \\
c(\%)^{\mathrm{a}}\end{array}$} \\
\hline & $\begin{array}{c}\text { SwCNT-A- } \\
\text { PAL }\end{array}$ & $\begin{array}{c}\text { SwCNT-B- } \\
\text { PAL }\end{array}$ & $\begin{array}{c}\text { SwCNT-A- } \\
\text { PAL }\end{array}$ & $\begin{array}{c}\text { SwCNT-B- } \\
\text { PAL }\end{array}$ \\
\hline 1 & 48,4 & 49,2 & 36,9 & 36,7 \\
\hline 2 & 49,2 & 48,5 & 24,2 & 37,2 \\
\hline 3 & 49,0 & 48,8 & 3,8 & 36,2 \\
\hline 4 & 49,3 & 47,4 & - & 34,2 \\
\hline 5 & 45,6 & 46,3 & - & 17,5 \\
\hline 6 & 43,7 & 42,4 & - & 5,7 \\
\hline 7 & 42,5 & 42,3 & - & 2,2 \\
\hline
\end{tabular}

A hagyományos rázatott lombikos rendszerekben jól müködő immobilizált PAL (SwCNT-B-PAL) készítményt folyamatos üzemű mikroreaktorban is alkalmaztuk (8. Ábra) az $(E)-4$ akrilsavra történő ammónia addíciós reakciójában, mely során enantiomertiszta L-aminosav állítható elő.

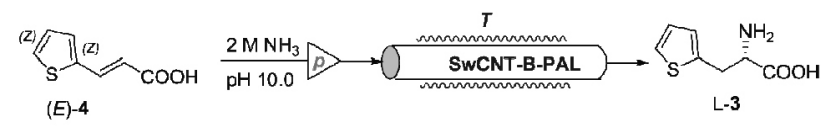

8.Ábra. Szén nanocsövön immobilizált PAL (SwCNT-B-PAL) készítménnyel katalizált $(E)-\mathbf{4}$ akrilsavra történő ammónia addíció folyamatos üzemű mikroreaktorban.

$\mathrm{Az}$ átfolyásos reaktor alkalmazása jóval hatékonyabb biotranszformációkat tesz lehetővé, mint az eddig vizsgált szakaszos, rázatott lombikos rendszer, hiszen $30^{\circ} \mathrm{C}$-on már 2 óra elteltével $60 \%$-os konverzió (c) volt elérhető (9. Ábra). Érdekes jelenség azonban, hogy $50^{\circ} \mathrm{C}$-nál a konverzió 60 \%-ról 49 \%-ra csökken, ezt követően a hőmérséklet emelésével a konverzió emelkedik. Ez a jelenség az enzim szerkezet hőmérsékletfüggésével magyarázható. Az enzim másodlagos szerkezeti elemei $40-50^{\circ} \mathrm{C}$ között reverzibilis változást szenvednek. Ettől magasabb hőmérsékleten $60^{\circ} \mathrm{C}$-on, a szén nanocsöveken rögzített PAL 80 órán át stabilan müködik folyamatos üzemben (9. ábra).

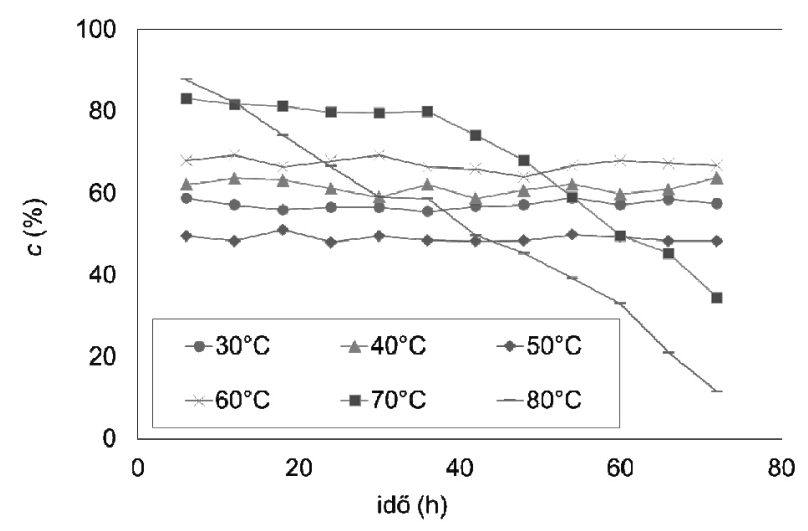

9.Ábra. Szén nanocsövön immobilizált PAL (SwCNT-B-PAL) készítménnyel $(E)-4$ akrilsav ammónia addíciójának hőmérsékletfüggése folytonos átfolyású mikroreaktorban.

A GDE biszepoxi vegyülettel módosított szén nanocsövekkel tehát egy új, stabil hordozórendszert hoztunk létre, amely több reakciócikluson keresztül erélyes körülmények között is hatékonyan alkalmazható aminosavak enantiomertiszta szintézisére szakaszos és folyamatos üzemü reaktorokban is. ${ }^{19}$

\subsection{Fenilalanin ammónia-liáz vizsgálata, új aciklikus, nem-aromás szubsztráttal MagneChip mikrofludikai eszköz segítségével}

Ez idáig nem született egységesen, elfogadott mechanizmus az ammónia-liázok katalitikus müködésével kapcsolatban. A javasolt mechanizmusok közti dilemmákat egy aciklusos aminosavat segítségével döntöttük el. Amennyiben a PAL az aciklusos, nem aromás aminosavat szubsztrátjaként elfogadja, úgy az kizárhatná az eddig leginkább javasolt Friedel-Crafts típusú mechanizmust. ${ }^{20}$ Kísérleteinkhez a racém racém-propargilglicint (PG), mint aciklusos aminosavat választottuk, a PAL enzimet pedig mágneses nanorészecskékhez rögzítettük (MNP). A PG és föképp a belőle keletkező eliminált termék rendkívül instabil. A hagyományos enzimkinetikai mérések instabil anyag esetében nehézkesek, sok anyagot, gyors munkavégzést és 
szigorú körültekintést igényelnek. A PG enzimkatalizált próbareakcióját ezért a kis anyagmennyiségeket igénylő, gyors, és folyamatosan in-line követhető mágneses nanorészecskékkel feltölthető mikrofludikai eszközben (MagneChip)vizsgáltuk (10. Ábra). Az enzim reakciót deuterált oldószerben hajtottuk végre, ily módon a chip-et elhagyó minta egyidejüleg ${ }^{1} \mathrm{H}$ NMR segítségével is vizsgálható.

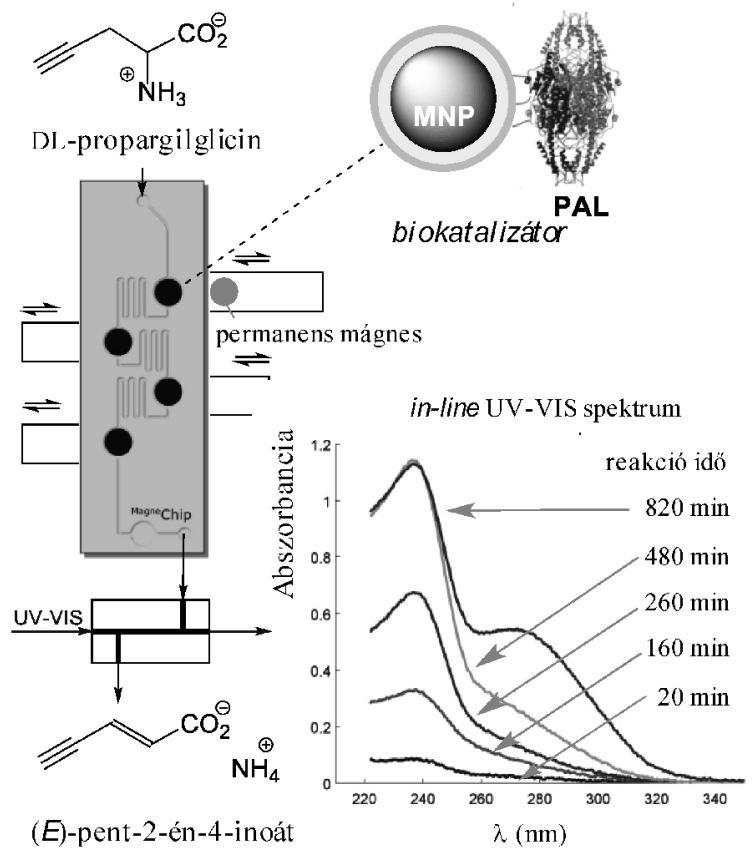

10. Ábra. A racém-propargilglicin eliminációjának vizsgálata MNP-PAL biokatalizátorral töltött MagneChip mikrofluidikai eszközben

A chipben folytatott mérések során azt tapasztaltuk, hogy már 20 perc eltelte után ë $=242 \mathrm{~nm}$ hullámhossz körül abszorbancia növekedés látszik a chipet elhagyó oldat teljes UV-VIS spektrumában. Az az idő függvényében abszorbancia folyamatosan növekedett, majd 480 perc után maximalizálódott $\left(\mathrm{A}_{242}=1,2\right)$. A spektrumban megjelenő jellegzetes abszorbancia növekedés, majd a telítődés jelensége nagy valószínüséggel az enzim reakció jelenlétére utal. Ezt igazolta az összegyüjtött minta ${ }^{1} \mathrm{H}$ NMR spektruma is, melyben termékként várt $(E)$-pent-2-én-4-inoátra egyértelmüen utaló olefinkötések $\delta=6,34(d)$ és 6,85 (d) ppm csatolási állandókkal azonosíthatóak voltak. A MagneChip kísérletek és NMR mérések egyértelmüen arra utalnak, hogy a PAL katalizálja a racém-propargilglicin ammónia eliminációt, tehát sikerült kísérletesen kizárni a Friedel-Crafst típusú reakciómechanizmust és megerősíteni az $N$-MIO intermedieren át történő mechanizmust. ${ }^{21}$

\section{3. Összefoglalás}

Doktori munkám során olyan különböző nanostruktúrált rendszerek létrehozásával foglalkoztam, melyek alkalmasak lehetnek enzimek hatékony immobilizálásra. Célunk volt olyan, variábilis és robusztus nanoszerkezetü biokatalizátorok fejlesztése, melyek eredményesen és jól alkalmazhatóak szakaszos üzemü, illetve folytonos átfolyású mikroreaktorokban történő biotranszformációkra. Enzimek nanopórusos szol-gél mátrixba ágyazásával és funkcionalizált szén nanocső hordozókon történő kovalens rögzítésével sikeresen hoztunk létre olyan biokatalizátorokat, melyek kevesebb enzimmennyiséggel hatékonyabb biokatalitikus folyamatokat tesznek lehetővé. A mátrixba zárt enzimek több reakció cikluson át aktvitás és enantiomerszelektivitás vesztés nélkül alkalmazhatóak, valamint eredményesek folytonos üzemü biotranszformációkban is. Elektrosztatikus szálképzéssel polimer nanoszálakban immobilizált lipázok aktivitását többszörösére fokoztuk egyszerü additívek alkalmazásával, melyek a későbbiekben ígéretesek lehetnek folytonos üzemü membrán reaktorokkal megvalósítható enantiomerszelektív szintézisekben. Mágneses nanorészecskéken rögzített enzimekkel mikrofluidikai chipekben hatékony biotranszformációkat valósítottunk meg, melyek rendkívül egyszerüen és gyorsan adhatnak kísérletes bizonyítékot egy adott enzim múködési mechanizmusával kapcsolatos feltételezésekre, segítségükkel karakterizálható, finomhangolható egy adott biotranszformációs folyamat.

\section{Kísérleti leírások}

\subsection{Lipáz rögzítése szol-gél módszerrel}

$390 \mu 1$ TRIS pufferhez (0,05 M, pH 7,5), 2001 PEG1000 oldatot (4\% v/v vizes oldat) és 20012 -propanolt (IPA) adtunk, majd az elegyet szobahőmérsékleten 10 percen át rázattuk (450 rpm). Ezt követően $50 \mathrm{mg}$ Pseudomonas fluorescens lipáz készítményt, $3 \mathrm{mmol}$ szilán prekurzor megfelelő mólarányú elegyét, végül 1001 nátrium-fluorid oldatot (1 M, vizes oldat) adtunk az elegyhez, folyamatos intenzív rázatás mellett. A mintákat 12 órán át szobahőmérsékleten rázattuk, majd a létrejött géleket üvegszürőn IPA, desztillált víz, IPA és $n$-hexán (minden esetben $10 \mathrm{ml}$ ) segítségével mostuk, a kapott fehér por állagú mintákat 24 órán át szobahőmérsékleten száradni hagytuk.

\subsection{Fenilalanin ammonia-liáz térhálósítása kovalens keresztkötő ágensekkel}

$1 \mathrm{ml}$ fenilalanin ammonia-liáz enzim TRIS pufferes oldatához (enzim koncentráció $2 \mathrm{mg} \mathrm{ml}^{-1}$, TRIS: 0,1M; lipáz esetében pH 7,5; ammónia-liáz esetében $\mathrm{pH}$ 8,8) $3 \mathrm{ml}$ kicsapószert adtunk (lipáz esetében acetont, ammonia-liáz esetében etanolt), majd az elegyet 10 percen át $4^{\circ} \mathrm{C}$-on vagy szobahőmérsékleten rázattuk. Ezt követően $80 \mu \mathrm{l}$ glutáraldehidet (GA) vagy glicerin diglicidil étert (GDE) adtunk az elegyhez folyamatos rázatás mellett. 24 óra elteltével a mintákat centrifugáltuk $\left(2200 \times \mathrm{g}, 15 \mathrm{~min}, 8^{\circ} \mathrm{C}\right)$, a felülúszót dekantáltuk, majd az üledéket háromszor TRIS pufferrel (0,1M; pH 8,8), végül etanollal mostuk.

\subsection{Lipáz rögzítése poli(vinil-alkohol) (PVA) nanoszálakban elektrosztatikus szálképzés segítségével}

$100 \mu 1$ lipáz oldathoz (enzim koncentráció: 35,5 mg $\mathrm{ml}^{-1}$ nátrium-foszfát pufferben; $0,1 \mathrm{M}, \mathrm{pH} 7,5$ ) hozzáadtuk a megfelelő additívet ( $5 \mathrm{v} / \mathrm{v} \%$ az enzimoldatra vonatkoztatva) majd az elegyet 10 percen át rázattuk szobahőmérsékleten. Ezt követően az elegyhez 675 mg PVA oldatot adtunk (10 $\mathrm{m} / \mathrm{m} \%$-os vizes oldat), majd a mintát 20 percen keresztül 
ultrahangoztuk. Az electrospinning készülékben a mintát fecskendő pumpa segítségével $\left(0,8-1,0 \mathrm{ml} \mathrm{h}^{-1}\right.$ áramlási sebességgel) az emitterbe juttattuk, majd a rendszert nagyfeszültség alá helyeztük (U 20 kV). A képződő terméket alufóliával borított lap kollektoron gyüjtöttük (emitter-kollektor távolság $10 \mathrm{~cm}$ ).

\subsection{Fenilalanin ammonia-liáz rögzítése funkcionalizált szén nanocsöveken}

$20 \mathrm{mg}$ karboxil- vagy epoxicsoportokkal funkcionalizált szén nanocső hordozóhoz $1 \mathrm{ml}$ fenilalanin ammonia-liáz TRIS pufferes oldatát adtuk (enzim koncentráció: $2 \mathrm{mg} \mathrm{ml}^{-1}$, TRIS: 0,1 M; pH 8,8), majd az elegyet szobahőmérsékleten egy éjszakán át intenzíven rázattuk. Ezt követően a mintát membránszürő segítségével szürtük $(0,45 \mu \mathrm{m})$, majd háromszor desztillált vízzel mostuk.

\subsection{MNP-PAL alkalmazása MagneChip mikrofluidikai eszközben megvalósított biotranszformációban}

4 mg MNP-PAL készítményhez és 4 mg PEG 4000-et és 1,5 $\mathrm{ml}$ ultratiszta víz és 2-propanol 5:1 arányú (v/v) elegyét adtuk, majd 15 percen keresztül ultrahangozás segítségével

\section{Hivatkozások}

1. Schmid, A.; Dordick, JS.; Hauer, B.; Kiener, A.; Wubbolts, M.; Witholt, B. Nature. 2001, 409, 255-268. https://doi.org/10.1038/35051736

2. Demarche, P.; Junghanns, C. Nair, RR.; Agathos, SN.; Biotechnol. Adv. 2012, 30, 933-953. https://doi.org/10.1016/j.biotechadv.2011.05.013

3. Hanefeld, U.; Cao, L.; Magner, E. Chem. Soc. Rev. 2013, 42, 6211-6212. https://doi.org/10.1039/c3cs90042h

4. Sheldon, RA.; Pelt, S. Chem. Soc. Rev. 2013, 42, 6223-6235. https://doi.org/10.1039/C3CS60075K

5. DiCosimo, R.; McAuliffe, J.; Poulose, AJ.; Bohlmann, G. Chem. Soc. Rev. 2013, 42, 6437-6474. https://doi.org/10.1039/c3cs35506c

6. Ansari, SA.; Husain, Q. Biotechnol. Adv. 2012, 30, 512-523.

https://doi.org/10.1016/j.biotechadv.2011.09.005

7. Gupta, MN.; Kaloti, M.; Kapoor, M.; Solanki, K. Artif Cells Blood Substit Immobil Biotechnol. 2011, 39, 98-109. https://doi.org/10.3109/10731199.2010.516259

8. Avnir, D.; Coradin, T.; Lev, O.; Livage, J. J. Mater. Chem. 2006, 16, 1013-1030. https://doi.org/10.1039/B512706H

9. Sheldon, RA. Appl. Microbiol. Biotechnol. 2011, 92, 467-477. https://doi.org/10.1007/s00253-011-3554-2

10. Huang, XJ.; Chen, PC.; Huang, F.; Ou, Y.; Chen, MR.; Xu, ZK. J. Mol. Cat. B. 2011, 70, 95-100. https://doi.org/10.1016/j.molcatb.2011.02.010

11. Feng, W.; Pi, J. Biotechnol. Adv. 2011, 29, 889-895. Https://doi.org/10.1016/j.biotechadv.2011.07.007 szuszpendáltuk. Ezt követően a folyamatosan rázatott szuszpenziót enyhe levegőnyomással (0,2-0,3 bar) a MagneChip belsejébe juttattuk, ahol az MNP-PAL biokatalizátort neodímium mágnesek segítségével rögzítettük a reakciókamrákban. A rendszert $35^{\circ} \mathrm{C}$-ra termosztáltuk, majd a feltöltött chipet $1 \mathrm{ml}$ nátrium-karbonát tartalmú deutérium-oxiddal $(50 \mathrm{mM}) 20$ percen keresztül mostuk, majd DL- propargilglicin (DL-6) nátrium-karbonát tartalmú deutérium-oxidos oldatát (DL-6: $40 \mathrm{mM}$; nátrium-karbonát $50 \mathrm{mM})$ tápláltuk rá a chipre $\left(0,6 \mu 1\right.$ perc $^{-1}$ áramlási sebességgel). A MagneChipet elhagyó reakcióközeget in-line átfolyó cellás UV-VIS spektrofotométer segítségével követtük nyomon, majd a mintát ${ }^{1} \mathrm{H}$ NMR segítségével analizáltuk.

\section{Köszönetnyílvánítás}

Köszönetünket szeretnénk kifejezni az NKFIH-nak (NN-103242-) és az új Széchenyi Terv Programnak (TÁMOP-4.2.1/B-09/1/KMR-2010-0002) és a COST Action CM1303 (SysBiocat) programnak a kutatás anyagi hátterének biztosításáért.

12. Govan, J.; Gunko Y. Nanomaterials. 2014, 4, 222-241. https://doi.org/10.3390/nano4020222

13. Ender F., Weiser D., Nagy B., Bencze L. C., Paizs C., Pálovics P., Poppe L.: J. Flow. Chem. 2016, 6, 43-52. https://doi.org/10.1556/1846.2015.00036

14. Tomin, A.; Weiser, D.; Hellner, G.; Bata, Z,; Corici, L.; Péter, F.; Koczka, B,; Poppe, L. Proc. Biochem. 2011, 46, 52-58. https://doi.org/10.1016/j.procbio.2010.07.021

15. Weiser, D.; Boros, Z.; Hornyánszky, G.; Tóth, A.; Poppe, L. Proc. Biochem. 2012, 47, 428-434. https://doi.org/10.1016/j.procbio.2011.11.023

16. Reetz, MT.;Tielmann, P.; Wiesenhöfer, W.; Könen, W.; Zonta, A. Adv. Synth. Catal. 2003, 345, 717-728. https://doi.org/10.1002/adsc.200303016

17. Weiser, D.; Sóti, P.L.; Bánóczi, G.; Bódai, V.; Kiss, B.; Gellért, Á.; Nagy, ZK.; Koczka, B.; Szilágyi, A.; Marosi, G.; Poppe, L. Tetrahedron. 2016, 72, 7335-7342. https://doi.org/10.1016/j.tet.2016.06.027

18. Weiser, D.; Varga, A.; Kovács, K.; Nagy, F.; Szilágyi, A.; Vértessy, GB.; Paizs, C.; Poppe, L. Chem CatChem. 2014, 6, 1463-1469. https://doi.org/10.1002/cctc.201300806

19. Bartha-Vári, JH.; Toşa, MI.; Irimie, FD.; Weiser, D.; Boros, Z.; Vértessy,BG.; Paizs, C.; Poppe, L. ChemCatChem, 2015, 7, 1122-1128. https://doi.org/10.1002/cctc.201402894

20. Poppe, L.; Rétey, J. Angew. Chem. 2005, 44, 3668-3688. https://doi.org/10.1002/anie.200461377

21. Weiser, D.; Bencze, CL.; Bánóczi, G.; Ender, F.; Kókai, E.; Szilágyi A.; Vértessy, GB.; Farkas, Ö.; Paizs, C.; Poppe, L. ChemBioChem, 2015, 16, 2257-2402. https://doi.org/10.1002/cbic.201500520 


\section{Nanostructured systems for enzyme immobilization}

During my PhD work I developed various nano structured systems that could be used for effective enzyme immobilization. Our aim was to develop such variable and robust nanostructured bio catalysts, which can be well-applied in biotransformations in batch or continuous flow reactors.

During embedding enzymes in nonporous sol-gel matrix mono- and di- substituted organosilane molecules have been used as gelling precursors. Di-substituted precursors (dimethyl, diphenyl, methylphenyl-dietoxisilane) have not yet been applied for immobilizing enzymes in sol-gel method. By example of lipase it has been showed that precursors containing two methyl groups are able to create matrices which can be multiple specific activity of enzymes and also provide support for effective selection of enantiomers. Sol-gel matrix containing di-substituted precursors is able to stabilize enzymes, which can be used without loss of activity and selectivity during many reaction cycles. Enantiomerically pure compounds can be produced by embedded lipases immobilized in sol gel matrices using continuous-flow reactor.

Enzyme crosslinking has been performed successfully by new bis epoxides. Lipase and ammonia-lyase preparations have stable morphology due to their covalent binding epoxy groups. They have significantly better bio catalytic activity comparing to frequently applied enzymes crosslinked by glutaraldehyde. Bisepoxydes are less toxic and they can be proper agents in crosslinking enzymes and functioning of variety of substrate.

Lipase immobilization has been carried out successfully by electrostatic spinning in poly (vinyl alcohol) fibers. The specific activity of enzymes fixed in nano fibers with high specific surface area has been dramatically increased comparing to non immobilized native enzymes. By using substrate analog additives the activity and enantiomer selectivity of lipases could be further enhanced. Polyethylene glycol 400 showed outstanding performance on functionality of immobilized lipases. Organosilane additives (octyl and phenyltriethoxysilane) are able to behave as analogies of lipase substrates. They can promote the immobilization of lipases in active conformation resulting improved activity of biocatalyzers.

Phenylalanin ammonia-lyase covalent binded on carboxyl and epoxy functionalized carbon nano tubes have been applied successfully in elimination and creation of chiral amino acids. Stable immobilization could be achieved between enzyme and carrier by advantageous carbon nano tubes modified with bis epoxides. Immobilized enzyme products can be applied in several cycles efficiently in creation of several enantio pure amino acids in batch or continuous flow reactors. It was able to create stable magnetic functionalized nano particles which can be used for effective immobilization of enzymes.

Phenylalanine ammonia-lyase immobilized on magnetic nano particles can be effectively used as biocatalyst in continuous flow micro fluidic reactor so called Lab-On-a-Chip (MagneChip). Biocatalytic activity of enzyme can be increased three times in MagneChip reaction chambers comparing to can be increased three times compared to conventional batch reactor systems.

We are able to identify MagneChip can give answer to opportunity for extremely small amount of materials in a short time to respond to clear long-lasting questions about operating mechanism of the enzyme.

This part contains a detailed and descriptive extract of the article in English using 9pt letters, single spacing, justified paragraphs and a 10pt space after the paragraphs. This part should not contain any schemes or tables but it might refer to those in the body of the main article. 